International Research Journal of Management, IT \& Social Sciences
Available online at https://sloap.org/journals/index.php/irjmis/
Vol. 6 No. 5, September 2019, pages: 17 24
ISSN: 2395-7492
https://doi.org/10.21744/irjmis.v6n5.684

\title{
Effect of Career Orientation on Organizational Commitments Mediated by Job Satisfaction
}

\author{
Ni Wayan Merry Nirmala Yani ${ }^{\text {a }}$ \\ Agoes Ganesha Rahyuda ${ }^{\text {b }}$
}

Article history:

Received: 27 March 2019

Accepted: 31 May 2019

Published: 05 August 2019

\section{Keywords:}

career;

commitment;

employee;

job satisfaction;

organizational;

\begin{abstract}
The sample used was non-civil servant employees at the Department of Industry and Trade in Denpasar City, totaling 75 respondents using saturated sampling to collect the samples. This study used PLS (Partial Least Square) analysis technique. The results of the study found that career orientation had a positive effect on organizational commitment, career orientation had a positive effect on job satisfaction, job satisfaction had a positive effect on organizational commitment, and job satisfaction acted as a partial mediating variable on the effect of career orientation relationships on organizational commitment. The implications of this study indicate that in order to increase the organizational commitment of non-civil servant employees of the Denpasar Industry and Trade Service, it is necessary to pay attention to the factors of career orientation and job satisfaction. This shows that career orientation and job satisfaction factors greatly affect the behavior of non-civil servant employees in increasing their commitment to achieving organizational goals. Organizations should provide clear career orientations to non-civil servant employees and able to give opportunities to develop their values at work.
\end{abstract}

2395-7492@ Copyright 2019. The Author.

This is an open-access article under the CC BY-SA license (https://creativecommons.org/licenses/by-sa/4.0/) All rights reserved.

Author correspondence:

Yani, N. W. M. N.

Faculty of Economics and Business Udayana University, Bali, Indonesia.

Email address: merrynirmala72@gmail.com

\section{Introduction}

Organizational commitment is a psychological state characterized by a relationship between employees and the organization which leads to a several behaviors such as employee attendance, job satisfaction, turnover intensity, organizational citizen behavior, work motivation, employee performance, and also implied employee behavior in the workplace (Eslami \& Gharakhani, 2012; Radosavljević et al., 2017). Conceptually organizational commitment consists of three types, namely affective, normative, and continuance commitment (Anari, 2012). High normative commitment employees are for those who believe that they are obliged to remain in the organization, continuance commitment

${ }^{\text {a }}$ Faculty of Economics and Business, Udayana University, Denpasar, Indonesia

${ }^{\mathrm{b}}$ Faculty of Economics and Business, Udayana University, Denpasar, Indonesia 
refers to awareness in leaving the organization since it would be costly, while affective commitment refers to the positive emotional attachment of employees to the organization which leads to involve agreement on organizational goals and individuals (Radosavljević et al., 2017). Highly committed employees will help the organization to achieve its goals.

Career orientation reflects individual preferences regarding certain opportunities, circumstances, and career types (Gerber et al., 2009). Through career orientation, an individual reflects the dedication of work, organization, and career rather than family (Sharjeel et al., 2016). There are several types of prominent career orientation, they are the boundaryless career and protean career (Briscoe \& Finkelstein, 2009). Protean career models emphasize individual goals as a driving force for individual career direction, while the boundaryless model attempts to explain how individuals manage their career progress in various organizational structures (Supeli \& Creed, 2016).

According to Briscoe \& Finkelstein (2009), a research study found that career orientation consisted of two dimensions namely unlimited career attitudes (limitless mindset, organizational mobility) and protean career attitudes (independent career management, value-based career management). The research study stated that organizational mobility preferences were negatively related to affective commitment, protean career attitudes (independent career management and career orientation driven by values) and boundless mindset showed no relation to affective commitment. Furthermore, the borderless mindset showed a negative relationship with normative commitment, and none of the protean career attitudes were negatively related to normative commitment or with continuance commitment. Furthermore, in Alonderienè \& Šimkevičiūte (2018), research stated that the regression analysis findings showed affective commitment positively predicted by independent career management and limitless thinking patterns and negatively predicted by career orientation driven by organizational mobility values and preferences. Continuance commitment predicted negatively by independent career management and organizational mobility preferences.

Supeli \& Creed (2016), in their study, stated that protean career orientation predicted higher job satisfaction, organizational commitment and higher intention to quit the job. It is also stated that workers with protean career orientation levels were higher when they were not meet the needs and were not given the opportunity to develop their values in the workplace, would decrease job satisfaction which led to reducing their commitment and increasing their interest in leaving the organization. Based on several studies above it can be said that career orientation affects organizational commitment.

The effect of career orientation on organizational commitment is also happening due to the effect of job satisfaction. Job satisfaction plays an important in an organization, where its role to determine employees' behavior, in other words, job satisfaction shows the employee's positive attitude towards their work (Leite et al., 2014; Kong et al., 2018; Sukayana \& Putri, 2019). Sano (2016), in his research, stated that career orientation affects job satisfaction, where job satisfaction is differently perceived by each employee according to the level of career they have. McMurtrey et al., (2015), in his study, said that job satisfaction would be higher for those with a dominant technical career orientation compared to managerial career orientation in a computer-assisted software engineering environment. From this study, it can be seen that career orientation has affected job satisfaction. Further research by Fu \& Deshpande (2014), described that job satisfaction has a significant direct impact on organizational commitment where the research is conducted in Chinese insurance companies. Furthermore, the study Srivastava (2013), found that job satisfaction is positively related to organizational commitment.

\section{Literature Review and Hypothesis}

At present, there is a reality where organizations should deal with competitive pressure. To survive and able to improve competitiveness, one of the management concepts developed is organizational commitment (Serna et al., 2017). Organizational commitment is the level of trust and support of employees towards organizational goals and has the desire to remain within the organization (Sani, 2013; Kawiana et al., 2018; Sari et al., 2019). Organizations certainly require high committed employees to realizing organizational goals, so that an organization must be able to increase the commitment of its employees.

To increase employee commitment, organizations should have valuable offers to employees. One of the values that can be offered is a clear career orientation. Workers with higher protean career orientation levels would experience a digression in job satisfaction when their needs are not met and not given the opportunity to develop their values in the workplace, they also would feel the organization is less relevant to them which leads to reducing their commitment to the organization, and increasing their interest in leaving the organization (Supeli \& Creed, 2016). In addition to the effect of career orientation on organizational commitment, there is also the effect of other variables called job satisfaction. Research conducted by Ismail \& Razak (2016) proved that job satisfaction is closely related to 
organizational commitment, wherein the context of this research the administrator focuses on matters relating to employee job satisfaction. The majority of respondents say that the level of intrinsic satisfaction, extrinsic satisfaction, and organizational commitment was high. This situation states that the ability of administrators to provide sufficient intrinsic satisfaction and extrinsic satisfaction could increase employee commitment to support organizational goals and strategies. From the description above, the conceptual framework of this research can be seen in Figure 1.

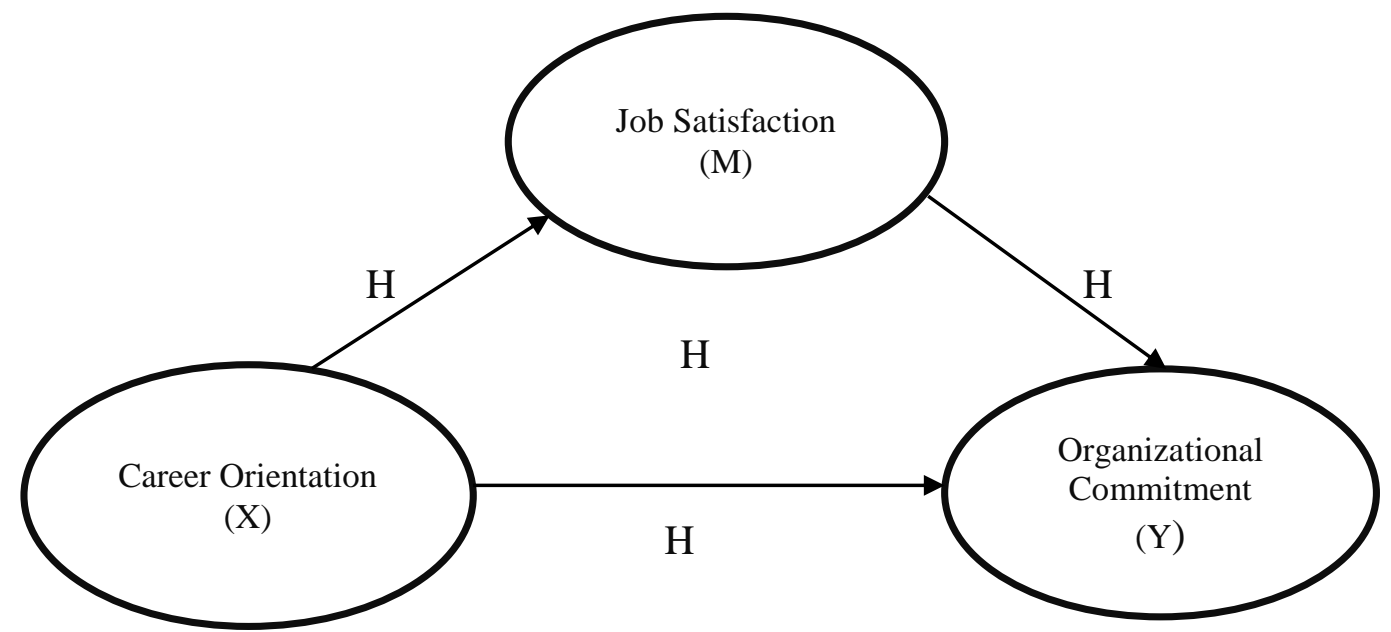

Figure 1. Conceptual framework

$\mathrm{H}_{1}$ : Career orientation has a positive effect on organizational commitment.

$\mathrm{H}_{2}$ : Career orientation has a positive effect on job satisfaction.

$\mathrm{H}_{3}$ : Job satisfaction has a positive effect on organizational commitment.

$\mathrm{H}_{4}$ : Job Satisfaction mediates career orientation towards organizational commitment.

\section{Materials and Methods}

The scope of this research was carried out on non-civil servant employees in the Department of Denpasar Industry and Trade Service as respondents. The location was chosen as the scope of the study due to the existence of several problems related to the commitment of non-civil servant employees in the Department of Denpasar Industry and Trade Service and the ease of access by researchers in conducting research.

The closed questionnaire was chosen as the data collection technique. Choice of answers was provided by the researcher by using Likert scale to measure the attitudes, opinions, and perceptions of respondents to organizational commitment, career orientation, and job satisfaction. Data were collected by giving questionnaires directly to respondents. The population was the total of all elements in a study. The population used in this study were employees of Department of Denpasar Industry and Trade Service. The sampling method in this study used a saturated sample method or census, which was a sampling technique using the entire population as research respondents. The number of non-civil servant employees at the Department of Denpasar Industry and Trade Service was 75.

The hypothesis testing being used is the t-test. Tests carried out by t-test on the inner model obtained p-value $<$ 0.05 (Alpha 5\%), the test means there is a significant effect of latent variables, which called career orientation variables offered to other latent variables, called organizational commitment and job satisfaction variables.

\section{Results and Discussions}

Testing the inner model or structural model was done to proof that there is a relationship between constructs, significance values and R-square of the research model. The results of testing the inner model can be seen in Figure 2.

Yani, N. W. M. N., \& Rahyuda, A. G. (2019). Effect of career orientation on organizational commitments mediated by job satisfaction. International Research Journal of Management, IT and Social Sciences, 6(5), 17-24. https://doi.org/10.21744/irjmis.v6n5.684 


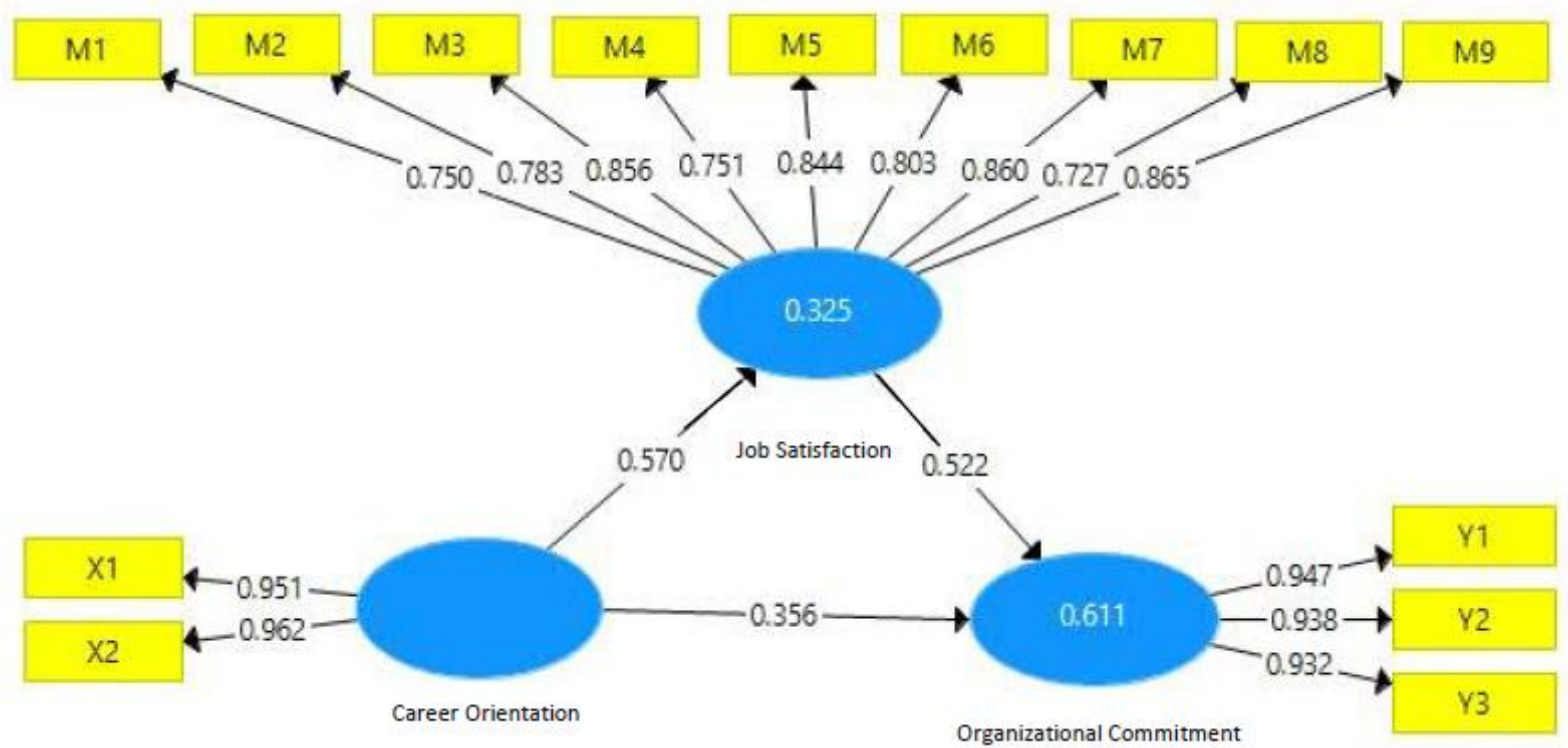

Figure 2. Structural Model

Structural models were evaluated using R-square for the dependent construct and t-test and the significance of the structural path parameter coefficients.

Table 1

$R$-square

\begin{tabular}{lc}
\hline \multicolumn{1}{c}{ Construct } & $R$ Square \\
\hline Job Satisfaction & 0.325 \\
Organizational Commitment & 0.611 \\
\hline Primary Data, 2019
\end{tabular}

In table 1 it can be seen if the R-square value of organizational commitment variable is 0.611 . This can be interpreted that $61.1 \%$ of the variability in organizational commitment was explained by variables of job satisfaction and career orientation, while $38.9 \%$ of organizational commitment variables are explained by variables outside the model. Likewise, the job satisfaction variable, $32.5 \%$ of its variability was explained by career orientation, while $67.5 \%$ of career orientation variables are explained by variables outside the model.

In addition to using R-square, the goodness of fit, the model was also measured using Q-Square predicate relevance for structural models, measuring how well the observations produced by the model and also its parameter estimates. Q-Square value > 0 indicates the model has predicate relevance, whereas if the Q-Square value $\leq 0$ indicates the model does not have predicate relevance. Based on Table 1, the value of predicate relevance $\left(Q^{2}\right)$ can be calculated, namely:

$$
\begin{aligned}
Q^{2} & =1-\left(1-R_{1}^{2}\right)\left(1-R_{2}^{2}\right) \\
& =1-(1-0.611)(1-0.325) \\
& =1-(0.389)(0.675) \\
& =1-0.262575 \\
& =0.737435 \approx 0.737
\end{aligned}
$$

The results of this calculation indicated that the value of $Q^{2}$ was greater than $0(0.737)$, so it can be interpreted that the model was good because it has a relevant predictive value, which equals to $73.7 \%$. This shows that variations in organizational commitment variables can be explained by the variables used, namely career orientation and job satisfaction variables, while the remaining $26.3 \%$ is explained by other variables that have not entered the model. 
Hypothesis testing

The significance of the estimated parameters provides very useful information about the relationship between the research variables. The basis used in testing the hypothesis is the probability (p-value) value found in the output path coefficients presented in Table 2 below.

Table 2

Path Coefficients

\begin{tabular}{lllll}
\hline Construct & Path Coefficient & T Statistics & $P$ Values & Description \\
\hline Job Satisfaction -> Organizational Commitment & 0,522 & 4,508 & 0,000 & Accepted \\
Career Orientation -> Job Satisfaction & 0,570 & 4,890 & 0,000 & Accepted \\
Career Orientation -> Organizational Commitment & 0,356 & 2,550 & 0,011 & Accepted \\
\hline
\end{tabular}

Primary Data, 2019

Hypothesis testing can be done using t-statistics or by looking at p-value with Alpha used at 0.05 . If the value of $\mathrm{t}-$ statistics $\geq$ t-table value $(1.99346)$ or $p$-value $<0.05$ then $\mathrm{H}_{0}$ is rejected and the research hypothesis is accepted. In Table 5.11 it can be seen that job satisfaction with organizational commitment has a correlation coefficient of 0.522 ; with the t-statistics value of $2.550(2.550 \geq 1.99346)$ and $\mathrm{p}$-value of $0.000(0.000<0.05)$ then $\mathrm{H}_{0}$ is rejected and the research hypothesis is accepted. This shows that there is a positive effect between variable job satisfaction and organizational commitment. The higher job satisfaction for employees of the Denpasar City Industry and Trade Ministry's non-civil servant, the higher the organizational commitment of the employees of the Denpasar Industry and Trade Ministry's non-civil servant.

Career orientation variables towards organizational commitment have a correlation coefficient of 0.356 ; with the t-statistics value of $4.508(4.508 \geq 1.99346)$ and with a p-value of $0.011(0.011<0.05)$ then $\mathrm{H}_{0}$ is rejected and the research hypothesis is accepted. This shows that there was a positive effect between career orientation on organizational commitment. The higher the career orientation promised by the organization to non-civil servant employees, the higher the organizational commitment of non-civil servant employees to the organization. Furthermore, career orientation variables on job satisfaction have a correlation coefficient of 0.570 ; with the t-statistics value of $4.890(4.890 \geq 1.99346)$ and with a p-value of $0.000(0.000<0.05)$ then $\mathrm{H}_{0}$ is rejected and the research hypothesis is accepted. This shows that there is a positive effect between career orientation on job satisfaction. The higher the career orientation promised by the organization to non-civil servant employees, the more satisfied non-civil servant employees are at work. Based on the data above, it can be concluded that the hypothesis in this study was entirely accepted.

\section{The Role of Job Satisfaction on Mediating the Effect of Career Orientation on Organizational Commitment}

The results of testing the direct effect of career orientation on organizational commitment have a p-value of 0.011 ; where this value is smaller than the Alpha used which is 5\% (0.05). This shows that there is a significant positive effect between career orientation on organizational commitment, with a coefficient of 0.356 . The addition of job satisfaction variables as mediating variables has a different effect on the direct relationship of career orientation to organizational commitment. Testing the mediating variables of company job satisfaction is done by calculating the value of Variance Accounted for (VAF) which can be seen in Table 2.

In Table 2 it can be seen that job satisfaction has a direct effect on organizational commitment of 0.522. Career orientation has a direct effect on organizational commitment of 0.356 . Career orientation has a direct effect on job satisfaction of 0.570 . The indirect effect between career orientation and organizational commitment is 0.297 . The total effect that is owned between job satisfaction and organizational commitment is 0.522 ; the effect of total career orientation with an organizational commitment of 0.653 ; and the total effect between career orientation and job satisfaction is 0.570 .

Yani, N. W. M. N., \& Rahyuda, A. G. (2019). Effect of career orientation on organizational commitments mediated by job satisfaction. International Research Journal of Management, IT and Social Sciences, 6(5), 17-24. https://doi.org/10.21744/irjmis.v6n5.684 
Table 3

Direct Effect, Indirect Effect, Total Effect, and VAF

\begin{tabular}{llll}
\hline \multirow{2}{*}{ Variable } & \multicolumn{1}{c}{ Direct Effect } \\
\cline { 2 - 4 } & Coefficient & $\begin{array}{l}\text { T Statistic } \\
(\mid \text { O/STDEV } \mid)\end{array}$ & P Value \\
\hline Job Satisfaction -> Organizational Commitment & 0.522 & 4.508 & 0.000 \\
Career Orientation -> Job Satisfaction & 0.570 & 4.890 & 0.000 \\
Career Orientation -> Organizational Commitment & 0.356 & 2.550 & 0.011 \\
Variable & Indirect Effect & & 0.000 \\
Career Orientation -> Org. Commitment & 0.297 & 4.198 & 0.000 \\
Variable & Total Effect & 0.000 \\
Job Satisfaction -> Organizational Commitment & 0.522 & 0.000 \\
Career Orientation -> Job Satisfaction & 0.570 & 4.8908 & \\
Career Orientation -> Organizational Commitment & 0.653 & 5.432 & \\
$V A F=\frac{\text { Indirect Effect }}{\text { Total Effect }}$ & 0.455 & & \\
$\quad=\frac{}{0.297}$ & & &
\end{tabular}

Primary Data, 2019

From the results of calculations in Table 3, it can be interpreted that the role of job satisfaction as a mediator has a VAF value of $0.455(45.5 \%)$. These results indicate that the job satisfaction variable has a role as a mediator between career orientation and organizational commitment variables. This shows that the more clearly the career orientation promised by the organization to non-civil servant employees, the more satisfied non-civil servant employees at work and will be able to increase the organizational commitment of employees to the organization, so the hypothesis that job satisfaction serves as a mediating relationship between career orientation and proven organizational commitment.

\section{Conclusion}

The results of this study provide theoretical implications for the development of human resource management science, specifically regarding the theory of social exchange, organizational commitment, career orientation, and job satisfaction. In this study shows that career orientation has a positive effect on organizational commitment, career orientation has a positive effect on job satisfaction, job satisfaction has a positive effect on organizational commitment, and job satisfaction is a mediation in the relationship between career orientation and organizational commitment. Thus it is hoped that this study can be empirical evidence for future research with related variables. The results of this study indicate that in order to increase the organizational commitment of the non-civil servant staff of the Department of Industry and Trade in Denpasar City, it is necessary to pay attention to the factors of career orientation and job satisfaction. This shows that career orientation and job satisfaction factors greatly affect the behavior of non-civil servant employees in increasing the commitment to achieve organizational goals. Organizations should provide clear career orientations and able to give the opportunity to develop the employees' values in the workplace so that they will be able to improve their job satisfaction. In addition to obtaining the appropriate salary, promotion, appropriate social benefits, rewards on extra work (besides of the job descriptions), good partnerships with the organisation's supervisor, appropriate organizational operational procedures, good coworkers, appropriate job description with the non-civil servant employee's position, and good communication will be able to increase the commitment of non-civil servant employees to the organization. Thus the more satisfied employees with their work, the higher their commitment to the organization. 
Research Limitations

1) The scope of the research is only limited to Department of Industry and Trade in Denpasar City so that the results of the study can also have differences related to the perception or level of interpretation of each respondent in other government organizations.

2) This research is limited to reviewing organizational commitment, job satisfaction, and career orientation so that it cannot examine more deeply the factors outside the variable. The next researcher can use other variables such as workload in increasing organizational commitment.

3) This research related to the determination of samples using saturated sample techniques, then for future research can apply other sample determination techniques, one of which is random sampling technique so that it can be generalized.

4) This study uses a cross-sectional time design or at a certain point in time, but on the other hand, this study observes the dynamics of conditions that each period undergoes changes because this research is important to be re-examined in the future.

Conflict of interest statement and funding sources

The authors declared that they have no competing interest.

Statement of authorship

The authors have a responsibility for the conception and design of the study. The authors have approved the final article.

Acknowledgments

The authors would like to thank the Editor of IRJMIS for their valuable time, support, and advice in completing the current study.

Yani, N. W. M. N., \& Rahyuda, A. G. (2019). Effect of career orientation on organizational commitments mediated by job satisfaction. International Research Journal of Management, IT and Social Sciences, 6(5), 17-24. https://doi.org/10.21744/irjmis.v6n5.684 


\section{References}

Alonderienè, R., \& Šimkevičiūtè, I. (2018). Linking protean and boundaryless career with organizational commitment: The case of young adults in finance sector. Baltic Journal of Management, 13(4), 471-487. https://doi.org/10.1108/BJM-06-2017-0179

Anari , N. N. (2012). Teachers: emotional intelligence, job satisfaction, and organizational commitment. Journal of Workplace Learning, 24(4), 256-269.

Briscoe, J. P., \& Finkelstein, L. M. (2009). The "new career" and organizational commitment: do boundaryless and protean attitudes make a difference?. Career Development International, 14(3), 242-260. https://doi.org/10.1108/13620430910966424

Eslami, J., \& Gharakhani, D. (2012). Organizational commitment and job satisfaction. ARPN Journal of Science and Technology, 2(2), 85-91.

Fu, W., \& Deshpande, S. P. (2014). The impact of caring climate, job satisfaction, and organizational commitment on job performance of employees in a China's insurance company. Journal of Business Ethics, 124(2), 339-349. https://doi.org/10.1007/s10551-013-1876-y

Gerber, M., Wittekind, A., Grote, G., \& Staffelbach, B. (2009). Exploring types of career orientation: A latent class analysis approach. Journal of Vocational Behavior, 75(3), 303-318. https://doi.org/10.1016/j.jvb.2009.04.003

Isma1l, A., \& Razak, M. R. A. (2016). Effect Of Job Satisfaction On Organizational Commitment. Management \& Marketing Journal, 14(1), 25-40.

Kawiana, I. G. P., Dewi, L. K. C., Martini, L. K. B., \& Suardana, I. B. R. (2018). The influence of organizational culture, employee satisfaction, personality, and organizational commitment towards employee performance. International Research Journal of Management, IT and Social Sciences, 5(3), 35-45.

Kong, H., Jiang, X., Chan, W., \& Zhou, X. (2018). Job satisfaction research in the field of hospitality and tourism. International Journal of Contemporary Hospitality Management, 30(5), $2178-2194$. https://doi.org/10.1108/IJCHM-09-2016-0525

Leite, N. R. P., Rodrigues, A. C. D. A., \& Albuquerque, L. G. D. (2014). Organizational commitment and job satisfaction: What are the potential relationships?. BAR-Brazilian Administration Review, 11(4), 476-495.

McMurtrey, M. E., Grover, V., Teng, J. T., \& Lightner, N. J. (2002). Job satisfaction of information technology workers: The impact of career orientation and task automation in a CASE environment. Journal of Management Information Systems, 19(2), 273-302. https://doi.org/10.1080/07421222.2002.11045719

Radosavljević, Ž., Ćilerdžić, V., \& Dragić, M. (2017). Employee organizational commitment. International Review, (1-2), 18-26.

Sani, A. (2013). Role of procedural justice, organizational commitment and job satisfaction on job performance: The mediating effects of organizational citizenship behavior. International Journal of Business and Management, 8(15), 57.

Sano, Y. (2016). Diversification of Regular Employees' Career Orientations and the Current Status of Careers and Working Styles. Japan Labor Review, 13(2), 46-69.

Sari, I. G. A. D. I., \& Dwirandra, A. (2019). The ability of organization commitment and moderate worked motivation by the effect of budget goal clarity in budgetary inaccuracy. International Research Journal of Management, IT and Social Sciences, 6(3), 11-17. https://doi.org/10.21744/irjmis.v6n3.622

Serna, M. D. C. M., Vega, J., \& Domenec, V. E. (2018). The influence of organizational commitment and learning orientation on innovation in SMEs. Contaduría y administración, 63(3), 11.

Sharjeel, M. Y., Siddiqui, H., \& Khwaja, G. (2016). Work-family conflict and career orientation amongst employed women in banks and hospitals. Pakistan Business Review, 17(4).

Srivastava, S. (2013). Job satisfaction and organizational commitment relationship: Effect of personality variables. Vision, 17(2), 159-167. https://doi.org/10.1177\%2F0972262912483529

Sukayana, G. A., \& Putri, I. A. D. (2019). Tri hita karana culture and organizational commitments moderate: effect of participation on budgetary slack. International Research Journal of Management, IT and Social Sciences, 6(4), 180-188. https://doi.org/10.21744/irjmis.v6n4.676

Supeli, A., \& Creed, P. A. (2016). The longitudinal relationship between protean career orientation and job satisfaction, organizational commitment, and intention-to-quit. Journal of Career Development, 43(1), 66-80. https://doi.org/10.1177\%2F0894845315581686 